\title{
Czy gospodarce polskiej grozi dewastacja budżetu i katastrofa finansowa? ${ }^{2}$
}

\section{WPROWADZENIE}

Do najważniejszych argumentów krytycznych, kierowanych wobec programu gospodarczego nowego rządu można zaliczyć:

- tani populizm i rozdawnictwo,

- nie są podane źródła finansowania tych wydatków - żeby komuś coś dać, trzeba komuś innemu coś zabrać,

- polityka ta grozi dewastacją budżetu i katastrofą finansową.

Zarzuty powyższe najbardziej dosadnie sformułował były minister finansów J. Rostowski: „Na te obietnice, które składa Prawo i Sprawiedliwość pieniędzy nie ma i w ciągu czterech najbliższych lat nie będzie (...). Spełnienie ich doprowadzi do totalnej katastrofy finansów publicznych oraz całej gospodarki” (Rostowski, 2015).

Na niektóre z tych zarzutów można odpowiedzieć we wstępie. Ponieważ używa się zarzutu o tanim populizmie i rozdawnictwie należy przypomnieć, że budżet w każdym nowoczesnym państwie spełnia m.in. funkcję redystrybucyjną. Polega ona na przesuwaniu dochodów od osób o wyższych dochodach do osób o niższych dochodach oraz na finansowaniu z dochodów budżetowych transferów na rzecz osób o niższych dochodach. W rezultacie przeciętna skłonność

\footnotetext{
${ }^{1}$ Adres korespondencyjny: Wyższa Szkoła Bankowa w Poznaniu, ul. Powstańców Wlkp. 5, 61-895 Poznań; e-mail: jaroslaw.mielcarek@wsb.poznan.pl. ORCID: 0000-0002-7614-5914.

${ }^{2}$ Pierwszy raz koncepcja ta została zaprezentowana przez autora na XV Otwartym Seminarium Naukowym na Wyższej Szkole Bankowej w Poznaniu w dniu 02.03.2016 r., w odczycie pt. „Czy Polsce grozi dewastacja budżetu i katastrofa finansowa?", czyli przed uruchomieniem polityki fiskalnej przez nowy rząd. Drugi raz została przedstawiona w dniu 23.03.2017 r. na XVI Otwartym Seminarium Naukowym na Wyższej Szkole Bankowej w Poznaniu w odczycie pt. „Czy Polsce grozi dewastacja budżetu i katastrofa finansowa? Wnioski rok po I odczycie.” Można zatem stwierdzić, że jest to w znacznym stopniu nie wyjaśnienie ex post rezultatów polityki gospodarczej nowego rządu, lecz ich prognoza, sporządzona przed uruchomieniem jej narzędzi.
} 
do konsumpcji w społeczeństwie rośnie i tym samym przeciętna skłonność do oszczędzania maleje. Doprowadza to do wzrostu PKB i dobrobytu społeczeństwa w porównaniu z sytuacją, gdyby budżet nie pełnił tej funkcji. Dlatego krytykę posługującą się argumentem o rozdawnictwie i tanim populizmie można uznać za nietrafną.

Pogląd, że aby komuś coś dać, trzeba komuś innemu coś zabrać, sięga swoimi korzeniami do czasu Wielkiego Kryzysu z lat 1929-1933. Krytyczna argumentacja brytyjskiego Ministerstwa Skarbu przeciwko idei robót publicznych w latach 19291931 przedstawiała się następująco: ,albo trzeba by dodrukować nowych pieniędzy, albo zmniejszyć wydatki na inne cele" (cyt za Skidelsky, 2012, s. 73) [czyli trzeba komuś zabrać - przyp. aut.]. J. Cochrane użył współcześnie podobnego argumentu: „Po pierwsze, jeżeli nie zamierza się dodrukowywać pieniędzy, to muszą one skądś pochodzić. Jeżeli rząd pożycza od ciebie dolara, to jest to dolar, którego nie wydasz albo nie pożyczysz jakiejś firmie, żeby mogła go zainwestować. Każdy dolar zwiększonych wydatków rządowych musi odpowiadać dolarowi zmniejszonych wydatków prywatnych" (Cochrane, 2009).

Osoby głoszące takie poglądy zapominają, że J.M. Keynes obalił prawo Saya i wykazał, że ex post możliwa jest równowaga między wydatkami i dochodami przy niepełnym wykorzystaniu czynników produkcji. Przytoczone uwagi krytyczne i poglądy odnoszą się do sytuacji gospodarczej z pełnym wykorzystaniem czynników produkcji i nie powinny być formułowane wobec sytuacji, gdy tak nie jest. Wówczas na najwyższym poziomie teoretycznym można stwierdzić, że nie poziom podatków określa poziom wydatków państwa, lecz, że poziom wydatków państwa określa wielkość podatków, czyli nikomu nie trzeba niczego zabierać, by sfinansować dodatkowy bodziec fiskalny.

Pozornie najwięcej racji ma J. Rostowski. Rzeczywiście wówczas, gdy był ministrem finansów na wszystko brakowało pieniędzy. W związku z tym istniała według niego konieczność sięgania po takie źródła, jak dochody z prywatyzacji, Funduszu Rezerwy Demograficznej, OFE czy wydłużenie wieku emerytalnego.

Zachodzi zatem potrzeba rozstrzygnięcia za pomocą naukowej analizy, czy krytyka ta jest słuszna. Jest to celem artykułu. Dyskusja naukowa nad kształtem polityki gospodarczej rządu powinna uwzględniać wszystkie istotne stanowiska merytoryczne. Jak do tej pory pomijano w niej podejście keynesowskie, mimo tego, że są autorzy, którzy wskazują na aktualność keynesizmu po globalnym kryzysie finansowym XXI wieku (w skrócie GKF) (Krugman, 2009; Skidelsky, 2011, 2012). P. Krugman stwierdził, że powróciła gospodarka depresyjna, którą scharakteryzował następująco: „Co to oznacza, że gospodarka depresyjna powróciła? Zasadniczo oznacza to, że po raz pierwszy za życia dwóch generacji niepowodzenia po stronie popytowej gospodarki - niewystarczające prywatne wydatki, aby wykorzystać dostępne zdolności produkcyjne - stały się wyraźnym i obecnym ograniczeniem dla pomyślności dużej części świata" (Krugman, 2009, s. 182). W tej sytuacji pozostaje jako narzędzie tylko polityka fiskalna, a to 
jest keynesizm. Keynesista H. Minsky, twórca hipotezy finansowej niestabilności, w proroczo zatytułowanej książce przepowiedział w latach 80 . XX wieku nadejście kryzysu podobnego do Wielkiego Kryzysu z lat 1929-1933. Opisany przez niego górny punkt zwrotny w cyklu finansowym został współcześnie nazwany momentem Minsky'ego i wszedł na stałe do języka ekonomii (Cassidy, 2008; Minsky, 1984, 1992, s. 6; Mielcarek, 2009; Whalen, 2007, s. 8). Australijski keynesista S. Keen napisał pracę wyjaśniającą powstanie GKF (Keen, 2001, 2011). W 2010 roku otrzymał nagrodę Revere Award for Economics za najlepszą prognozę nadejścia GKF (Cassander, 2010) na podstawie swoich poprzednich publikacji oraz raportów (Keen, 2007).

Można stwierdzić, że w 2016 r. został w gospodarce polskiej przeprowadzony eksperyment ekonomiczny. Polegał on na tym, że w warunkach przygotowanych przez poprzedni rząd założeń budżetu, które określały wielkość dochodów i wydatków oraz maksymalną wielkość deficytu budżetu nowy rząd zdecydował się na zwiększenie wydatków związanych z uruchomieniem programu Rodzina 500+ od drugiego kwartału 2016 r. Jest to dodatkowy bodziec fiskalny w warunkach niepełnego wykorzystania czynników produkcji oraz braku wpływu bodźca fiskalnego na przyrost inwestycji, eksportu i transferów. Można stwierdzić, że są to warunki gospodarki depresyjnej według definicji P. Krugmana.

Dyskusje nad programem nowego rządu doprowadziły do wyłonienia się dwóch grup przeciwstawnych poglądów. $Z$ jednej strony nastąpiła ostra jego krytyka $\mathrm{z}$ najdalej idącymi przewidywaniami dewastacji budżetu i katastrofy finansowej, a z drugiej strony jego wsparcie z przekonaniem, że znajdą się źródła finansowania tych dodatkowych wydatków i żadne katastrofalne skutki się nie zdarzą.

Powstaje wobec tego potrzeba podjęcia próby w dalszej części artykułu rozwiązania dwóch problemów, sformułowanych za pomocą następujących pytań:

- Czy realizacja programu gospodarczego rządu grozi katastrofą finansową?

- Czy realizacja programu gospodarczego rządu grozi dewastacją budżetu i jakie mogą być źródła sfinansowania dodatkowych wydatków budżetowych?

Aby rozwiązać te problemy niezbędne będzie rozbudowanie teorii J.M. Keynesa o koncepcję dodatkowego bodźca fiskalnego. Na główne jego elementy składać się powinny warunek stabilności finansowej w sytuacji dokonywania dodatkowych wydatków budżetowych w warunkach istnienia deficytu budżetowego, zmodyfikowany mnożnik fiskalny, przyrost podatków wywołany dodatkowym bodźcem fiskalnym, współczynnik stopnia pokrycia początkowego bodźca fiskalnego dodatkowymi dochodami podatkowymi, współczynnik niedoboru finansowania i niedobór finansowania oraz krańcowy współczynnik skłonności do konsumpcji jako residuum po potrąceniu od przyrostu popytu zagregowanego importu konsumpcyjnego, a od przyrostu PKB podatków i oszczędności. 


\section{CZY REALIZACJA PROGRAMU GOSPODARCZEGO RZĄDU}

\section{GROZI KATASTROFĄ FINANSOWĄ}

Badanie zagadnienia katastrofy finansowej wymaga podania definicji stabilności fiskalnej. W opracowaniu zostanie przyjęta definicja, podana przez L.L. Pasinettiego: „dług publiczny jest określony jako stabilny, gdy stosunek długu publicznego do PKB zmniejsza się, lub przynajmniej pozostaje stały" (Pasinetti, 1998, s. 104-105).

Realizacja programu gospodarczego rządu może wywołać katastrofę finansową, gdy naruszy jednorazowo w sposób zasadniczy warunek stabilności fiskalnej lub będzie go naruszać corocznie w dłuższym okresie, co doprowadzi do szybkiego zwiększenia się udziału długu publicznego w PKB i znacznego przekroczenia przez tę wielkość $60 \%$.

Nadając operacyjne znaczenie terminowi warunek stabilności fiskalnej należy określić graniczną wielkość krańcowej skłonności do konsumpcji, dla której nie zostanie naruszony warunek równowagi fiskalnej ${ }^{3}$, czyli udział długu publicznego w PKB jest stały:

$$
c_{g}=\frac{1}{1-m}-\frac{u+t}{1+i}
$$

Warunek stabilności fiskalnej przedstawia się następująco:

$$
c \geq c_{g}
$$

gdzie:

$c_{\mathrm{g}}-$ graniczny współczynnik krańcowej skłonności do konsumpcji,

$c$ - rzeczywisty współczynnik krańcowej skłonności do konsumpcji, określający, jaka część przyrostu dochodu jest przeznaczana na konsumpcję,

$m$ - współczynnik krańcowej skłonności do importu, określający, jaka część przyrostu dochodu wywołuje przyrost importu,

$u$ - udział długu publicznego w PKB w zakończonym roku budżetowym,

$t$ - krańcowa stopa opodatkowania przyrostu dochodów,

$i$ - stopa procentowa,

Jeżeli rzeczywisty współczynnik krańcowej skłonności do konsumpcji jest większy od granicznego współczynnika, to warunek stabilności fiskalnej jest spełniony i udział długu publicznego w PKB maleje pod wpływem bodźca fiskalnego. Zagrożenie katastrofą finansową w wyniku uruchomienia nowego bodźca fiskalnego wystąpi wtedy, gdy współczynnik rzeczywistej, krańcowej skłonności do konsumpcji będzie dużo niższy od współczynnika granicznego. Należy zatem wyznaczyć za pomocą podanej formuły wielkość granicznego współczynnika krańcowej skłonności do konsumpcji i porównać z istniejącą w społeczeństwie

${ }^{3}$ Formuła ta została wyprowadzona w (Mielcarek, 2011, s. 191-194). 
krańcową skłonnością do konsumpcji. Wielkość zastosowanych parametrów i obliczenie granicznego współczynnika krańcowej skłonności do konsumpcji podano w tabeli 1.

Tabela 1. Graniczny współczynnik krańcowej skłonności do konsumpcji [\%] w 2016 r.

\begin{tabular}{|c|c|c|c|c|}
\hline $\begin{array}{c}\text { Wskaźnik } \\
\text { importochłonności } \\
\text { konsumpcji } \\
m\end{array}$ & $\begin{array}{c}\text { Udział długu sektora } \\
\text { instytucji rządowych } \\
\text { i samorząowych } \\
\text { w PKB 2015 r. } u\end{array}$ & $\begin{array}{c}\text { Stopa } \\
\text { opodatkowania } \\
\text { PKB } \\
t\end{array}$ & $\begin{array}{c}\text { Stopa } \\
\text { procentowa } \\
i\end{array}$ & $\begin{array}{c}\text { Graniczna wielkość } \\
\text { krańcowej skłonności } \\
\text { do oszczędzania } \\
c_{g}\end{array}$ \\
\hline 21,293 & 51,12 & 33,40 & 1,645 & 43,90 \\
\hline
\end{tabular}

Źródło: opracowanie własne na podstawie: Roczne mierniki gospodarcze, cz. III. Pobrano z: http:// stat.gov.pl/wskazniki-makroekonomiczne/ (2018.05.07) i Rentowność hurtowych obligacji dwurocznych. Pobrano z: https://www.finanse.mf.gov.pl/web/wp/dlug-publiczny/bony-i-obligacje-hurtowe/baza-transakcji (2018.05.20).

Stopa procentowa dotyczy oprocentowania w skali rocznej hurtowych obligacji skarbowych, których sprzedaż w 2016 r. sfinansuje początkowo bodziec fiskalny. Rentowność roczna pierwszej emisji tych obligacji dwurocznych z 2016 r. wynosiła $1,645 \%$.

Sposób obliczenia wskaźnika importochłonności konsumpcji w 2016 r. z tabeli 1 podano w tabeli 2 .

Tabela 2. Wskaźnik importochłonności konsumpcji w 2016 r. Wielkości pieniężne w mln zl

\begin{tabular}{|l|c|}
\hline \multicolumn{1}{|c|}{ Wyszczególnienie } & Wielkości \\
\hline Import konsumpcyjny & 336293 \\
\hline Import zaopatrzeniowy dla produkcji produktów konsumpcyjnych & 59435 \\
\hline Razem & 395728 \\
\hline PKB & 1858468 \\
\hline m & $21,29 \%$ \\
\hline
\end{tabular}

Źródło: opracowanie własne na podstawie: GUS, 2017, Rocznik statystyczny handlu zagranicznego 2017, Zakład Wydawnictw Statystycznych, Warszawa, s. 90-91. Pobrane z: https://stat.gov.pl/obszary-tematyczne/roczniki-statystyczne/roczniki-statystyczne/rocznik-statystyczny-handlu-zagranicznego-2017,9,11.html (2018.05.15).

Import zaopatrzeniowy dla produkcji produktów konsumpcyjnych został obliczony z wykorzystaniem wskaźnika importochłonności eksportu, wynoszącego w 2014 r. $33 \%{ }^{4}$.

Stopa opodatkowanie PKB jest podana w tabeli 3.

${ }^{4}$ Ostatnia wielkość importochłonności eksportu dla Polski jest podana przez OECD dla $2014 \mathrm{r}$. i wynosi 33\% [OECD, Import content of exports. Pobrano z: https://data.oecd.org/trade/import-content-of-exports.htm (2018.06.02)]. Wielkość ta przyjęta jest również dla $2016 \mathrm{r}$. 
Tabela 3. Udział podatków w PKB [\%] w 2016 r.

\begin{tabular}{|c|c|c|c|}
\hline $\begin{array}{c}\text { Udział podatków } \\
\text { pośrednich w PKB }\end{array}$ & $\begin{array}{c}\text { Udział podatków } \\
\text { dochodowych w PKB }\end{array}$ & $\begin{array}{c}\text { Udział składek na ubezpieczenia } \\
\text { społeczne w PKB }\end{array}$ & $\begin{array}{c}\text { Udział podatków } \\
\text { w PKB }\end{array}$ \\
\hline 13,5 & 7,1 & 12,8 & $33,40 \%$ \\
\hline
\end{tabular}

Źródło: opracowanie własne na podstawie: Eurostat. Taxation trends in the European Union, 2018 edition, Publications Office of the European Union, 2018, s. 128. Pobranbe z: https://ec.europa.eu/taxation_customs/sites/taxation/files/taxation_trends_2018_country_chapter_poland.pdf(2018.06.02).

Przyjęto, że opodatkowanie krańcowych dochodów jest równe opodatkowaniu średniemu $\mathrm{z}$ tabeli 3.

Graniczna wielkość współczynnika krańcowej skłonności do konsumpcji wyniosła 43,9\%5. Tymczasem obliczony w tabeli 5 współczynnik rzeczywisty dla warunków średnich wynosi $63,27 \%$. Spełniony jest zatem warunek stabilności fiskalnej. Różnica między wartością graniczną a wartością rzeczywistą wskaźnika skłonności do konsumpcji oznacza, że mimo wzrostu długu publicznego spowodowanego dodatkowym bodźcem fiskalnym udział długu publicznego w PKB maleje. Należy podkreślić, że dla obliczonej w tabeli 5 wielkości rzeczywistego współczynnika skłonności do konsumpcji istnieje duża stopa marży bezpieczeństwa względem wskaźnika granicznego, wynosząca $30,62 \%$. Oznacza to, że dopiero spadek wskaźnika rzeczywistego o niemal jedną trzecią zrównałby jego wielkość z wartością graniczną. Jest to zupełnie nieprawdopodobne i z tego względu należy uznać wniosek, że uruchomienie początkowego bodźca fiskalnego nie naruszy warunku stabilności fiskalnej za potwierdzony.

\section{CZY REALIZACJA PROGRAMU GOSPODARCZEGO RZĄDU GROZI DEWASTACJĄ BUDŻETU?}

Aby rozwiązać problem, którego sformułowanie stanowi tytuł niniejszego punktu niezbędne jest podanie danych początkowych. Znajdują się one w tabeli 4.

Tabela 4. Dane początkowe dla roku 2016

\begin{tabular}{|l|r|}
\hline \multicolumn{1}{|c|}{ Wyszczególnienie } & Wielkości \\
\hline Bodziec fiskalny $\Delta G$ mld zł & 17,612 \\
\hline Przeciętne opodatkowanie PKB $t[\%]$ & 33,4 \\
\hline Współczynnik krańcowej importochłonność konsumpcji $m[\%]$ & 21,293 \\
\hline Współczynnik krańcowej skłonności do oszczędzania s względem dochodu netto [\%] & od 0 do 10 \\
\hline
\end{tabular}

Źródło: opracowanie własne na podstawie: [GUS, 2017, s. 121. Pobrane z: http://stat.gov.pl/z-prac-studialnych/opracowania-eksperymentalne/sytuacja-makroekonomiczna-w-polsce-w-2016-r-na-tle-procesow-w-gospodarce-swiatowej,2,6.html (2018.05.10)].

${ }^{5}$ Część parametrów z formuły (1) jest policzona jako wielkości średnie. Przyjęto, że są to również parametry krańcowe, co może powodować pewne błędy o niewielkich wartościach, które będą się częściowo znosić. 
Wartość początkowego bodźca fiskalnego jest określona przez realizację przez trzy kwartały 2016 r. programu Rodzina 500+. Wydatki z budżetu państwa na ten cel w 2016 r. wyniosły $17612 \mathrm{mln}$ zł (GUS, 2017, s. 121). Dwa następne parametry z tabeli 3 zostały już omówione w poprzednim punkcie. Krańcowy współczynnik skłonności do oszczędzania mógłby być przyjęty dla polskiego społeczeństwa niemalże na poziomie zerowym, bowiem dla gospodarstw domowych przeciętny współczynnik wyniósł w 2016 r. 2,8\% (Kolasa, Premik, 2017, s. 10). Dla przedsiębiorstw sfery niefinansowej oszczędności w $2016 \mathrm{r}$. spadły w porównaniu z $2015 \mathrm{r}$ o 29544 mln zł, czyli o 9,68\% (GUS, 2018, tabela S11). Zgodnie z przyjętymi we wprowadzeniu założeniami bodziec fiskalny nie wywołuje ani wzrostu inwestycji, ani wzrostu eksportu. W związku z tym, przyrost oszczędności przedsiębiorstw nie posłużyłby do finansowania ich inwestycji, a ewentualnie mógłby być przeznaczony na wzrost płac, co spowodowałoby wzrost współczynnika skłonności do konsumpcji. Aby uniknąć zarzutów, że przyjęto wielkość zbyt niską przeprowadzono symulację dla wielkości krańcowego współczynnika skłonności do oszczędzania od $0 \%$ do $10 \%$ dochodu netto, przy skoku wynoszącym 2,5 pkt proc.

Jeżeli nawet $\mathrm{w}$ punkcie początkowym niezbędne byłoby zaciągnięcie dodatkowego długu na sfinansowanie przynajmniej częściowo bodźca fiskalnego, to ze względu na możliwość jego szybkiej spłaty oraz niskie oprocentowanie obligacji hurtowych dwuletnich, emitowanych w 2016 r. pominięto odsetki od tego długu jako nieistotne ${ }^{6}$.

Skład danych w tabeli 4 uwzględnia występowanie w każdym obiegu działania mechanizmu mnożnika fiskalnego trzech kanałów wycieku z gospodarki dochodów: przyrosty importu, oszczędności i podatków. W rezultacie powracający do obiegu popyt staje się z każdym obiegiem coraz mniejszy. O wielkości tych wycieków przesądzają współczynnik krańcowej importochłonności, współczynnik krańcowej skłonności do oszczędzania i krańcowa stopa opodatkowania.

Jaki będzie efekt zadziałania mechanizmu mnożnika fiskalnego ${ }^{7}$ Można zauważyć, że przyrosty PKB w kolejnych obiegach tworzą malejący szereg geometryczny. Podane niżej formuły na składniki tej sumy w kolejnych obiegach mechanizmu mnożnika fiskalnego posłużyły do obliczenia tych wielkości:

$$
\sum_{i=1}^{\infty} \Delta Y_{i}=(1-m) \Delta G+(1-m)^{2} c \Delta G+(1-m)^{3} c^{2} \Delta G \ldots=(1-m) \Delta G\left[1+(1-m) c+(1-m)^{2} c^{2} \ldots\right]
$$

Ostateczną postać formuły na całkowity przyrost PKB pod wpływem początkowego bodźca fiskalnego otrzymano określając iloraz szeregu geometrycznego

${ }^{6}$ Dla pełnej kwoty wydatków finansowanej długiem odsetki rocznie wyniosłyby 17612 x 1,635\% $=290 \mathrm{mln} \mathrm{zt}$.

${ }^{7}$ Pierwszy koncepcję mnożnika przedstawił R.F. Kahn (1931, s. 173-198). Ekonomistą, który w pełni rozwinął i wykorzystał ją w analizie makroekonomicznej był J.M. Keynes (1965). 
$q$, który jest relacją poprzedzającego składnika do wcześniejszego, na przykład relacją trzeciego składnika do drugiego i wzór na sumę malejącego (zbieżnego) szeregu geometrycznego:

$$
S_{n}=a \frac{1}{1-q}
$$

gdzie $S_{n}$ jest sumą malejącego szeregu geometrycznego, a jego wyrazem początkowym i $q$ jego ilorazem. Z (3) wynika, że wyrazem początkowym jest jeden, a ilorazem

$$
q=(1-m) c
$$

Iloraz ten powinien być mniejszy od 1 i dodatni, aby szereg geometryczny był zbieżny:

$$
(1-m) c<1
$$

a to jest spełnione, gdy

$$
1-m<\frac{1}{c}
$$

Lewa strona nierówności (7) jest dodatnia i mniejsza od jeden, a jej prawa strona dla współczynnika skłonności do konsumpcji dodatniego i mniejszego od jeden jest większa od jeden, czyli warunek (6) jest zawsze spełniony, a szereg geometryczny (3) jest zawsze zbieżny. Suma malejącego szeregu geometrycznego (3) na podstawie (4) i (5) wynosi:

$$
\sum_{i=1}^{\infty} \Delta Y_{i}=(1-m) \Delta G \frac{1}{1-c+c m}=\frac{1-m}{1-c+c m} \Delta G=m_{f} \Delta G
$$

Mnożnik fiskalny, który jest określony przez współczynnik krańcowej skłonności do konsumpcji i współczynnik importochłonności konsumpcji wynosi:

$$
m_{f}=\frac{1-m}{1-c+c m}
$$

Przyrost PKB pod wpływem bodźca fiskalnego jest równy iloczynowi mnożnika fiskalnego (9) i dodatkowego wydatku państwa:

$$
\Delta Y=m_{f} \Delta G
$$

${ }^{8}$ Wielkość mnożnika fiskalnego można również obliczyć, posługując się formułą uwzględniającą import, wyprowadzoną w (Mielcarek, 2011, s. 193-194) i w odmienny sposób w (Łaski, Osiatyński, Zięba, 2010, s. 8-11). 
Stopa wzrostu PKB, wywołana bodźcem fiskalnym będzie wynosić:

$$
d=\frac{\Delta Y}{Y}=m_{f} \frac{\Delta G}{Y}
$$

Stopa ta jest większa od relacji dodatkowego bodźca fiskalnego do PKB o mnożnik fiskalny.

Przyrost dochodów podatkowych państwa obliczymy jako sumę poniższego szeregu geometrycznego:

$$
\begin{gathered}
\sum_{i=1}^{\infty} \Delta T_{i}=(1-m) t \Delta G+(1-m)^{2} c t \Delta G+(1-m)^{3} c^{2} t \Delta G \ldots=(1-m) t \Delta G 1\left[1+(1-m) c+(1-m)^{2} c^{2} \ldots\right]= \\
=t \Delta G \frac{1-m}{1-c+m c}=t_{f} \Delta G
\end{gathered}
$$

Przyrost podatków wywołany bodźcem fiskalnym równy jest iloczynowi stopy opodatkowania, mnożnika fiskalnego i wielkości bodźca fiskalnego.

Można już zająć się kluczowym punktem dla przedstawionych rozważań, całkowicie nieobecnym w dyskusjach o programie gospodarczym rządu. Potrzebna jest jeszcze odpowiedź na pytanie o stopień pokrycia początkowego bodźca fiskalnego dochodami podatkowymi budżetu państwa, określonymi przez działanie mechanizmu mnożnika fiskalnego:

$$
l=\frac{\sum_{i=1}^{\infty} \Delta T_{i}}{\Delta G}=\frac{t m_{f} \Delta G}{\Delta G}
$$

Tak długo, jak długo istnieją w gospodarce niewykorzystane czynniki produkcji stopień ten jest określony tylko przez dwa parametry - przez iloczyn krańcowej stopy podatkowej i wielkości mnożnika fiskalnego.

W kolejnym kroku należy określić współczynnik niedoboru finansowania, który wynosi:

$$
f=1-l=1-t m_{f}
$$

W sytuacji deficytu współczynnik ten określa potrzeby pożyczkowe państwa związane z uruchomieniem dodatkowego wydatku z budżetu państwa.

Znając współczynnik niedoboru finansowania można obliczyć niedobór finansowania:

$$
F=f \Delta G=\left(1-t m_{f}\right) \Delta G
$$


Pozostaje jeszcze określenie krańcowego współczynnika skłonności do konsumpcji jako residuum:

$$
\Delta C=\Delta D-\Delta M-\Delta T-\Delta S=\Delta Y-\Delta T-\Delta S
$$

i stąd otrzymujemy formułę na współczynnik krańcowej skłonności do oszczędzania w wyniku podzielenia (16) przez przyrost PKB:

$$
c=\frac{\Delta C}{\Delta Y}=1-\frac{\Delta T+\Delta S}{\Delta Y}=1-\frac{t \Delta Y+(1-t) s \Delta Y}{\Delta Y}=1-[t+(1-t) s]
$$

gdzie:

d - stopa wzrostu PKB,

$\Delta \mathrm{Y}$ - przyrost $\mathrm{PKB}$ wywołany bodźcem fiskalnym,

$\Delta \mathrm{G}-$ przyrost wydatków budżetu,

$m$ - krańcowy współczynnik importochłonności przyrostu konsumpcji,

$m_{f}-$ mnożnik fiskalny,

$\sum_{i=1}^{\infty} \Delta T_{i} \quad$ - przyrost podatków wywołany bodźcem fiskalnym,

$l$-współczynnik pokrycia finansowego początkowego bodźca fiskalnego,

$f$ - współczynnik niedoboru finansowania,

$F$ - niedobór finansowania,

$\Delta \mathrm{C}$ - przyrost konsumpcji wywołany bodźcem fiskalnym,

$\Delta \mathrm{D}$ - przyrost zagregowanego popytu konsumpcyjnego,

$\Delta \mathrm{M}$ - przyrost importu konsumpcyjnego,

$\Delta \mathrm{S}$ - przyrost oszczędności wywołany bodźcem fiskalnym,

$s$ - współczynnik krańcowej skłonności do oszczędzania.

Krańcowy współczynnik do konsumpcji jest residuum po potrąceniu od przyrostu popytu konsumpcyjnego importu konsumpcyjnego, a od przyrostu PKB podatków i oszczędności.

W tabeli 5 określone są zbiorczo skutki uruchomienia bodźca fiskalnego.

Tabela 5. Skutki uruchomienia bodźca fiskalnego ${ }^{9}$

\begin{tabular}{|l|c|c|c|c|c|}
\hline Współczynnik skłonności do oszczędzania $s$ & $0 \%$ & $2,5 \%$ & $5,0 \%$ & $7,5 \%$ & $10,0 \%$ \\
\hline 1 & 2 & 3 & 4 & 5 & 6 \\
\hline Współczynnik importochłonności konsumpcji $m$ & $21,293 \%$ & & & & \\
\hline Stopa opodatkowania PKB $t$ & $33,400 \%$ & & & & \\
\hline Współczynnik skłonności do konsumpcji $c$ & $66,60 \%$ & $64,94 \%$ & $63,27 \%$ & $61,61 \%$ & $59,94 \%$ \\
\hline
\end{tabular}

${ }^{9}$ Mnożnik fiskalny dla roku 2016 kształtuje się w granicach odpowiadających najniższym wartościom wyznaczonym za pomocą dwóch metod przez K. Łaskiego, J. Osiatyńskiego i J. Ziębę (2010, s. 17-20). 


\begin{tabular}{|l|c|c|c|c|c|}
\hline \multicolumn{1}{|c|}{1} & 2 & 3 & 4 & 5 & 6 \\
\hline Mnożnik fiskalny $m_{f}$ & 1,6542 & 1,6098 & 1,5678 & 1,5279 & 1,4900 \\
\hline Przyrost wydatków państwa 500+ $\Delta \mathrm{G}$ & 17612 & & & & \\
\hline Przyrost PKB $\Delta \mathrm{Y}$ & 29133 & 28352 & 27612 & 26910 & 26242 \\
\hline PBK 2015 Y & 1799392 & & & & \\
\hline Stopa wzrostu PKB 2016 & $1,62 \%$ & $1,58 \%$ & $1,53 \%$ & $1,50 \%$ & $1,46 \%$ \\
\hline Przyrost podatków $\Delta \mathrm{T}$ & 9730 & 9470 & 9222 & 8988 & 8765 \\
\hline $\begin{array}{l}\text { Stopień pokrycia bodźca fiskalnego } \\
\text { dodatkowymi dochodami budżetowymi } l\end{array}$ & $55,25 \%$ & $53,77 \%$ & $52,36 \%$ & $51,03 \%$ & $49,77 \%$ \\
\hline Stopień niedoboru finansowania $f$ & $44,75 \%$ & $46,23 \%$ & $47,64 \%$ & $48,97 \%$ & $50,23 \%$ \\
\hline Niedobór finansowania & 7882 & 8142 & 8390 & 8624 & 8847 \\
\hline
\end{tabular}

Źródło: opracowanie własne.

Przyjęliśmy, że bazowy model odpowiada krańcowemu współczynnikowi skłonności do oszczędzania, wynoszącemu 5\%. Skutki uruchomienia bodźca fiskalnego dla tego modelu przedstawiają się następująco:

- warunek stabilności finansowej - współczynnik skłonności do konsumpcji został obliczony za pomocą (17) i jego wielkość wynosi 63,27\%. Jest znacznie wyższy od granicznego współczynnika skłonności do konsumpcji i nie grozi polskiej gospodarce na skutek uruchomienia bodźca fiskalnego naruszenie warunku stabilności finansowej (2),

- efekt mnożnikowy - mnożnik fiskalny obliczony za pomocą (9) wynosi 1,5678, co oznacza, że każda złotówka dodatkowego wydatku państwa wywoła przyrost PKB o $1,5678 \mathrm{zł}$.

- efekt dochodowy - przyrost PKB obliczony za pomocą (8), wywołany dodatkowym bodźcem fiskalnym wynosi $27612 \mathrm{mln}$ zł, a stopa jego wzrostu, obliczona za pomocą (11) jest równa $1,53 \%$, co oznacza, że uruchomienie dodatkowego bodźca fiskalnego miało znaczący wpływ na końcową stopę wzrostu PKB w 2016 r.

- efekt podatkowy - przyrost podatków (12) wywołany uruchomieniem dodatkowego bodźca fiskalnego wynosi $9222 \mathrm{mln}$ zł, a to oznacza, że stopień pokrycia dodatkowego bodźca fiskalnego dodatkowymi dochodami podatkowymi (13) wynosi $52,36 \%$. Ponad połowa wydatku wynikającego z uruchomienia w 2016 programu Rodzina 500+ zostanie sfinansowana w wyniku zadziałania efektu podatkowego,

- efekt niedoboru finansowania - stopień niedoboru finansowania (14) wynosi 47,64\%, a niedobór finansowania (15) równy $8390 \mathrm{mln}$ zł określa wielkość potrzeby znalezienia dodatkowych źródeł ich finansowania. Wystąpienie efektu podatkowego powoduje, że nie potrzeba znaleźć źródła finansowania na równowartość dodatkowego wydatku z budżetu państwa, lecz na kwotę nieco niższą, niż połowa tej wartości.

W tabeli 6 przedstawione są możliwe źródła finansowania niedoboru finansowania. 
Tabela 6. Źródła finansowania niedoboru finansowania wydatków na 500+

\begin{tabular}{|l|r|}
\hline \multicolumn{1}{|c|}{ Wyszczególnienie } & Wielkości \\
\hline Zysk z NBP & 7861 \\
\hline Aukcja częstotliwości LTE & 9203 \\
\hline Podatek od aktywów instytucji finansowych & 3506 \\
\hline Podatek od sklepów wielkopowierzchniowych & 0 \\
\hline Razem z czterech źródeł & 20570 \\
\hline Przyrost dochodów podatkowych w 2016 r. bez podatku od aktywów bankowych & 9959 \\
\hline Ogółem & 30529 \\
\hline Przyrost wydatków budżetowych w 2016 r. & 29100 \\
\hline Deficyt budżetu planowany na 2016 r. & 54740 \\
\hline Deficyt budżetu wykonany w 2016 r. & 46159 \\
\hline Stopa spadku deficytu względem planu & $18,59 \%$ \\
\hline
\end{tabular}

Źródło: opracowanie własne na podstawie: [Ministerstwo Finansów, 2017, Sprawozdanie z wykonania budżetu państwa za okres od 1 stycznia do 31 grudnia 2016 r. Omówienie, s. 15, 34, 35, 46 i 49. Pobrano z: https://www.mf.gov.pl/documents/764034/6023712/20170531_Omowienie+sprawozdania+za+2016+r. pdf (2017.07.15); NBP, 2016, Sprawozdanie finansowe Narodowego Banku Polskiego na dzień 31 grudnia 2015 roku, s. 9. Pobrano z: http://www.nbp.pl/statystyka/rachunkowosc/Sprawozdanie_finansowe_ NBP_2015.pdf (2018.05.10)].

Należy zaznaczyć, że dochody z pierwszych trzech źródeł były znane w $2015 \mathrm{r}$. Wpływy zrealizowane z czterech pierwszych źródeł, uwzględnionych w ustawie budżetowej na 2016 r. (ustawa budżetowa na rok 2016 z dnia 25 lutego 2016 r.) wyniosły $20570 \mathrm{mln}$ zł. Przyrost dochodów podatkowych w $2016 \mathrm{r}$. bez podatku od aktywów niektórych instytucji finansowych był równy $9959 \mathrm{mln} \mathrm{zf}^{10}$. Cztery pierwsze źródła plus przyrost dochodów podatkowych stanowiły kwotę 30529 i mogły być źródłem finansowania bodźca fiskalnego. Uruchomienie wydatków od II kw. 2016 r. w kwocie 17612 mln zł na realizację programu Rodzina 500+ nie doprowadziło ani do dewastacji budżetu, ani do katastrofy finansowej. Wniosek ten potwierdza spadek deficytu wykonanego w 2016 r. względem deficytu planowanego w ustawie budżetowej na rok 2016 o 18,59\%.

Dane w tabeli 5 i 6 nie potwierdzają poglądu, że żeby komuś coś dać, należy komuś innemu odebrać. Wydatki budżetowe ogółem zrealizowane w 2016 r. były wyższe o $29100 \mathrm{mln}$ zł, czyli wzrosły w porównaniu z 2015 r. o 8,77\%. Po odjęciu od przyrostu wydatków kwoty wydatków na 500+ otrzymana będzie wielkość $11488 \mathrm{mln}$ zł, a stopa ich wzrostu wyniesie 3,46\%, czyli wielkość przekraczającą w 2016 r. stopę wzrostu PKB. Wielkości te są wyrażone nominalnie, a w ujęciu realnym są jeszcze wyższe, bowiem w 2016 r. wystąpiła deflacja.

${ }^{10}$ Uniknięto w ten sposób podwójnego sumowania tego podatku w tabeli 6 . Całkowity przyrost dochodów podatkowych wyniósł w 2016 r. $13465 \mathrm{mln}$ zł, a stopa ich wzrostu osiągnęła wielkość $5,19 \%$. 
Dlaczego eksperyment się udał? Można na to pytanie odpowiedzieć, że jego sukces wynikał z zadziałania mechanizmu mnożnika dla mnożnika fiskalnego wynoszącego ok. 1,6. Ale taka odpowiedź rodzi następne pytanie, dlaczego mnożnik fiskalny był większy od jeden.

Znaczenie miały proporcje podziału polskich gospodarstw domowych na ricardiańskie i keynesowskie ${ }^{11}$. W ricardiańskich gospodarstwach domowych polityka fiskalna wpływa na wydatki prywatne w wyniku pojawiania się oczekiwań co do kształtowania się opodatkowania ${ }^{12}$. W reakcji na wzrost wydatków budżetowych finansowanych przyrostem długu następuje w nich spadek konsumpcji i wzrost oszczędności.

Keynesowskie gospodarstwa domowe reagują w sposób odmienny od ricardiańskich gospodarstw na przyrost wydatków budżetowych (Gali, Lopez-Salido i Valles, 2007). Nie mają wpływu na ich zachowanie przewidywane zmiany polityki podatkowej i polityki fiskalnej. Ich wydatki konsumpcyjne są funkcją bieżących dochodów, czyli wydają dodatkowe dochody otrzymane w rezultacie prowadzonej przez państwo polityki fiskalnej. $Z$ tego powodu to nie wielkość podatków określa wielkość wydatków budżetowych, lecz wielkość wydatków budżetowych w przybliżeniu określa wielkość dochodów podatkowych. Można zauważyć, że zachowanie tych gospodarstw odpowiada pierwszej części znanego twierdzeniu M. Kaleckiego, że robotnicy wydają tyle, ile zarabiają, a kapitaliści zarabiają tyle, ile wydają (Kalecki, 1979, s. 8).

W gospodarkach krajów wysoko rozwiniętych dominują ricardiańskie gospodarstwa domowe. Gdyby w Polsce istniała podobna struktura gospodarstw domowych, to eksperyment $\mathrm{z}$ dodatkowym bodźcem fiskalnym nie powiódłby się. $\mathrm{W}$ takich warunkach mnożnik fiskalny miałby wartość równą jeden lub byłby nawet mniejszy od jeden.

W polskim społeczeństwie dominują gospodarstwa domowe keynesowskie. W szczególności dotyczy to beneficjentów programu Rodzina $500+{ }^{13}$. Dlatego mnożnik fiskalny mógł mieć wartość ok. 1,6.

M. Lubiński wskazuje, że ,gospodarstwa domowe mogą się zachowywać wedle jednego z tych wzorców zależnie od stanu koniunktury i kondycji gospodarstwa domowego" (Lubiński, 2015, s. 9). Przykładem nietrwałości zachowań charakterystycznych dla ricardiańskich gospodarstw domowych może być wzmocnienie zachowań gospodarstw domowych w sposób keynesowski, w tym również ricardiańskich przez to, że dodatkowy bodziec fiskalny w 2016 r. nie był finansowany ani zwiększeniem podatków, ani rząd nie deklarował, że zostanie on sfinansowany z przyrostu deficytu budżetu.

${ }^{11}$ Zagadnienie ricardiańskich i keynesowskich gospodarstw domowych jest szeroko analizowane w kontekście mnożnika fiskalnego w: (Lubiński, 2015, s. 9-13).

${ }^{12}$ Charakterystyka zachowań ricardiańskich gospodarstw domowych bazuje na równoważności Ricardo-Barro (Barro, 1974, 1979).

${ }^{13}$ To stwierdzenie odnosi się również do realizowanego od 2017 r. obniżenia wieku emerytalnego. 


\section{Podsumowanie}

Cele artykułu zostały zrealizowane. Rozwiązano problemy, sformułowane za pomocą następujących pytań:

- Czy realizacja polityki gospodarczej rządu grozi katastrofą finansową?

- Czy realizacja polityki gospodarczej rządu grozi dewastacją budżetu i jakie mogą być źródła sfinansowania dodatkowych wydatków budżetowych?

Wyniki analizy związanej z warunkiem równowagi fiskalnej stanowią podstawę do udzielenia odpowiedzi na tytułowe zapytanie czy realizacja polityki gospodarczej rządu grozi katastrofą finansową. Przedstawione zostały merytoryczne argumenty, z których wynika, że na tak postawione pytanie należy odpowiedzieć negatywnie.

Główne konkluzje artykułu są następujące:

- nikomu nie trzeba niczego zabierać, by sfinansować dodatkowy bodziec fiskalny w 2016 r.,

- budżet w każdym nowoczesnym państwie spełnia m.in. funkcję redystrybucyjną, dlatego krytyka posługującą się tezą o rozdawnictwie i tanim populizmie jest nietrafna,

- przedstawiony warunek stabilności fiskalnej nie zostanie naruszony przez dodatkowy wydatek, nie grozi zatem katastrofa finansowa spowodowana polityką gospodarczą rządu,

- dodatkowe wydatki mogą zostać sfinansowane z czterech źródeł:

- zysku NBP za 2015 r., przekazanego do budżetu w 2016 r.,

- wpływów z aukcji częstotliwości LTE,

- podatku od aktywów banku, wprowadzonego w 2016 r.,

- przyrostu dochodów podatkowych w 2016 bez podatku od aktywów bankowych ${ }^{14}$;

Istnienie dochodów z tych źródeł oznacza, że nie ma zagrożenia dewastacji budżetu. Również spadek zrealizowanego deficytu budżetu w porównaniu z jego wielkością planowaną na 2016 r. o 18,59\% nie potwierdza poglądu, że realizacja polityki gospodarczej obecnego rządu doprowadzi do dewastacji budżetu.

Przedstawione $\mathrm{w}$ artykule wyniki powstały $\mathrm{w}$ rezultacie rozbudowy teorii J. Keynesa o koncepcję dodatkowego bodźca fiskalnego. Na główne jego elementy składa się warunek stabilności finansowej w sytuacji dokonywania dodatkowych wydatków budżetowych wówczas, gdy istnieje już deficyt budżetowy, zmodyfikowany mnożnik fiskalny, przyrost podatków wywołany dodatkowym bodźcem fiskalnym, współczynnik stopnia pokrycia początkowego bodźca fiskalnego dodatkowymi dochodami podatkowymi, współczynnik niedoboru finansowania i niedobór finansowania oraz krańcowy współczynnik skłonności do konsumpcji

${ }^{14} \mathrm{~W}$ następnych latach przyrost dochodów podatkowych, szczególnie z VAT-u w wyniku uszczelnienia systemu podatkowego oraz $\mathrm{w}$ mniejszym stopniu wynikający ze zwiększonej stopy wzrostu PKB i pojawienia się umiarkowanej inflacji, która zwiększa stopę wzrostu nominalnego PKB będzie źródłem finansowania dodatkowych wydatków socjalnych. 
jako residuum po potrąceniu od przyrostu popytu importu konsumpcyjnego, a od przyrostu PKB podatków i oszczędności.

Sukces eksperymentu, polegającego na uruchomieniu dodatkowego bodźca fiskalnego w warunkach istniejącego deficytu budżetowego wynikał z tego, że w gospodarce polskiej dominują keynesowskie gospodarstwa domowe. W rezultacie takiej struktury gospodarstw domowych mnożnik fiskalny mógł być większy od jeden, a większa część dodatkowego wydatku budżetowego mogła być sfinansowana przez przyrost podatków.

Wobec zaprezentowanych rozważań może być sformułowany zarzut, że podane efekty zadziałania mechanizmu mnożnika fiskalnego nie są określone dokładnie. Podobne zarzuty były formułowane wobec teorii J.M. Keynesa. W odpowiedzi na nie sformułował on następujący argument: It is better to be roughly right than precisely wrong - lepiej jest mieć mniej więcej rację, niż bardzo dokładnie się mylić. Nawiązując do tego argumentu można stwierdzić, że myliły się bardzo dokładnie te osoby, które twierdziły, że wprowadzenie w życie programu gospodarczego rządu wywoła dewastację budżetu lub katastrofę finansową, że żeby komuś dać, trzeba komuś innemu zabrać, a także, że jest to tani populizm i rozdawnictwo.

\section{BiBLIOGRAFIA}

Barro, R.J. (1974). Are Government Bonds Net Welth?. Journal of Political Economy, 82 (6), $1095-1117$.

Barro, R.J. (1979). On the Determination of the Public Debt. Journal of Political Econo$m y, 87$ (5), 940-971.

Cassander, (2010). Revere Award for Economics. Pobrane z: http://www.debtdeflation. com/blogs/2010/05/14/revere-award-for-economics (2012. 06.20).

Cassidy, J. (2008). The Minsky Moment. New Yorker, February 4. Pobrane z: http://www. newyorker.com/talk/comment/2008/02/04/080204taco_talk_cassid (2008.03.15).

Cochrane, J.H.(2009). Fiscal Stimulus, Fiscal Inflation, or Fiscal Fallacies? Pobrane z: http:// faculty.chicagobooth.edu/john.cochrane/research/Papers/fiscal2.htm (2014.05.04).

Gali, J., López-Salido, J.D., Vallés, J. (2007). Understanding the Effects of Government Spending on_Consumption. Journal of the European Economic Association, 1, $227-$ 270. DOI: $10.3386 / \mathrm{w} 11578$.

GUS (2017). Sytuacja makroekonomiczna w Polsce w 2016 r. na tle procesów w gospodarce światowej. Pobrane z: http://stat.gov.pl/z-prac-studialnych/opracowania-eksperymentalne/sytuacja-makroekonomiczna-w-polsce-w-2016-r-na-tle-procesow-w-gospodarce-swiatowej,2,6.html (2018.05.10).

GUS (2018). Niefinansowe rachunki kwartalne wg sektorów instytucjonalnych za okres od I kwartatu 2010 r. do I kwartału 2018 r., Tabela S11, Rachunki niefinansowe - sektor przedsiębiorstw niefinansowych w latach 2010-2018, ceny bieżące, w mln zł, Pobrane z: http://stat.gov.pl/obszary-tematyczne/rachunki-narodowe/kwartalne-rachunki-narodowe/niefinansowe-rachunki-kwartalne-wg-sektorow-instytucjonalnych-za-okres-od-i-kwartalu-2010-r-do-i-kwartalu-2018-r-,2,22.html (2018.06.02). 
Lubiński, M. (2015). Mnożnik fiskalny: reaktywacja. Gospodarka narodowa, 1 (275), styczeń-luty, 5-26.

Kahn, R.F. (1931). The Relation of Home Investment to Unemployment. Economic Journal, 41, 173-198.

Keen, S. (2001). Debunking Economics. The Naked Emperor Dethroned? London, New York: Zed Books Ltd. DOI: 10.2307/2223697.

Keen, S. (2007). The Recession We Can't Avoid? Steve Keen's Monthly Debt Report, November 2006, 6/01/2007. Pobrane z: http://keenomics.s3.amazonaws.com/debtdeflation_media/2007/03/SteveKeenDebtReportNovember2006.pdf (2007.05.23).

Keen, S. (2011). Debunking Economics - Revised, Expanded and Integrated Edition. The Naked Emperor Dethroned? London, New York: Zed Books Ltd.

Keynes, J.M. (1965). Ogólna teoria zatrudnienia, procentu i pieniądza. Warszawa: PWN.

Kolasa, A., Premik, F. (2017). Sytuacja finansowa sektora gospodarstw domowych w IV kw. 2016 r., nr 02/17, Warszawa: Departament Analiz Ekonomicznych NBP. Pobrane z: https://www.nbp.pl/publikacje/domowe/domowe_4_2016.pdf (2018.05.05).

Krugman, P. (2009). The Return of Depression Economics and the Crisis of 2008. New York: W.W. Norton \& Company.

Łaski, K., Osiatyński, J., Zięba, J. (2010). Mnożnik wydatków państwowych i szacunki jego wielkości dla Polski. Materiaty $i$ Studia, 246, Warszawa: Departament Edukacji i Publikacji NBP.

Mielcarek, J. (2009). Teoria niestabilności finansowej Hymana Minsky’ego. W: A. Bielawska, L. Dorozik, J. Iwin-Garzyńska (red.), Finanse 2009 - teoria i praktyka (s. 496-503). Szczecin: Wydawnictwo Uniwersytetu Szczecińskiego.

Mielcarek, J. (2011). Prowadzenie polityki keynesowskiej w polskiej gospodarce w warunkach narastającego długu publicznego. W: J. Stachalska-Targosz, J. Szostak (red.), Wyzwania dla uczestników rynków finansowych w obliczu współczesnego kryzysu ekonomicznego (s. 189-198), Zeszyty Naukowe Wyższej Szkoły Bankowej w Poznaniu, 35, Poznań.

Minsky, H.P. (1984). Can "It" Happen Again? Essays on Instability and Finance. New York: M.E. Sharpe, Inc.

Minsky, H.P. (1992). The Financial Instability Hypothesis. Working Paper No. 74, The Jerome Levy Economics Institute of Bard College, May, (s. 6). Pobrane z: http://www. levy.org/pubs/wp74.pdf (2007.02.10).

OECD, 2018, Import content of exports. Pobrane z: https://data.oecd.org/trade/import-content-of-exports.htm (2018.05.10).

Pasinetti, L.L. (1998). The myth (or folly) of the 3\% deficit/GDP Maastricht "parameter. Cambridge Journal of Economics, 22 (1), 103-116. DOI: 10.1093/oxfordjournals. cje.a013701.

Rostowski, J. (2015). Rostowski: obawiam się, że PiS spetni obietnice. To bytaby katastrofa dla budżetu. Pobrane z: https://tvn24bis.pl/z-kraju,74/jacek-rostowski-nie-ma-pieniedzy-na-obietnice-pis-u,588031.html (2015.11.27).

Skidelsky, R. (2011). The relevance of Keynes. Cambridge Journal of Economics, 35 (1), 1-13. Pobrane z: https://www.nbp.pl/badania/seminaria/15iii2013.pdf (2015.05.03). DOI: $10.1093 /$ cje/beq043.

Skidelsky, R. (2012). Keynes. Powrót mistrza. Warszawa: Wydawnictwo Krytyki Politycznej. Ustawa budżetowa na rok 2016 z dnia 25 lutego 2016 r., Dz.U. 2016 r., poz. 278. Pobrane z: http://dziennikustaw.gov.pl/du/2016/278/1 (2018.06.10). 
Whalen, C.J. (2007). The U.S. Credit Crunch of 2007. A Minsky Moment. The Levy Economics Institute of Bard College, Public Policy Brief, 92 (s. 8). Pobrane z: http:// www.levyinstitute.org/pubs/ppb_92.pdf(2008.03.15).

\section{Streszczenie}

Celem artykułu było rozwiązanie problemów, sformułowanych w postaci pytania: czy polskiej gospodarce grozi katastrofa finansowa i dewastacja budżetu w wyniku uruchomienia w 2016 r. przez rząd dodatkowych wydatków na program Rodzina 500+, czyli poddanie analizie naukowej głównych elementów krytyki wobec programu gospodarczego rządu. Zaprezentowane wyniki badań powstały dzięki posłużeniu się rezultatami rozbudowy teorii J.M. Keynesa o koncepcję dodatkowego bodźca fiskalnego. Uruchomienie go nie naruszyło warunku stabilności fiskalnej systemu i tym samym nie groziło katastrofą finansową. Sukces eksperymentu gospodarczego polegającego na uruchomieniu dodatkowego bodźca fiskalnego w warunkach deficytu budżetowego został osiągnięty dlatego, że w gospodarce polskiej dominują keynesowskie gospodarstwa domowe i w związku z tym mnożnik fiskalny jest większy od jeden. Mechanizm mnożnikowy wywołuje wówczas znaczący efekt podatkowy. W rezultacie niedobór finansowania okazał się mniejszy od 50\% wartości bodźca fiskalnego. Również spadek zrealizowanego deficytu budżetu w porównaniu z jego wielkością planowaną w ustawie budżetowej na 2016 r. nie potwierdził poglądu, że polityka gospodarcza obecnego rządu doprowadzi do dewastacji budżetu.

Słowa kluczowe: dodatkowy bodziec fiskalny, warunek stabilności fiskalnej, mnożnik fiskalny, keynesowskie gospodarstwo domowe, niedobór finansowania.

\section{Is the Polish economy in danger of the devastation of the budget and the financial disaster?}

\section{Summary}

The aim of the article was to solve the problems connected with the question: is the Polish economy threatened by a financial disaster and devastation of the budget as a result of additional government spending on the 2016 Family $500+$ program, i.e. carrying out to the scientific analysis of the main points of the criticism of the government economic program. The presented research results were created thanks to the development of the concept of an additional fiscal stimulus contributing to the development of J.M. Keynes's theory. Launching this stimulus did not breach the condition of fiscal stability of the system and thus there was no risk of a financial disaster. The success of the economic experiment of launching an additional fiscal stimulus in the budget deficit situation was achieved because Keynesian households dominate in the Polish economy and, therefore, the fiscal multiplier is greater than one. The multiplier mechanism then generates a significant tax effect. As a result, the funding shortfall turned out to be less than $50 \%$ of the value of the fiscal stimulus. Also, the decrease in the budget deficit, compared to its planned amount indicated in the 2016 budget law, did not confirm the view that the current government's economic policy would lead to the devastation of the budget.

Keywords: additional fiscal stimulus, condition of fiscal stability, fiscal multiplier, Keynesian household, shortage of financing.

JEL: B41, E12, H30, H50, H61, H62. 